\title{
Inter-Organizational Trust in the Competitiveness Pole: A Theoretical Analysis
}

\author{
Fateh Saci ${ }^{1}$, Chaker Boughanbouz ${ }^{2}$ \\ ${ }^{1}$ Department of Accounting and Finance, University of Renmin/Sino-French Institute, Suzhou, China \\ ${ }^{2}$ Department of Management, University of Nice/Gredeg-CNRS, Nice, France
}

Email address:

sacifateh@yahoo.fr (F. Saci), cboughan@gredeg.cnrs.fr (C. Boughanbouz)

\section{To cite this article:}

Fateh Saci, Chaker Boughanbouz. Inter-Organizational Trust in the Competitiveness Pole: A Theoretical Analysis. International Journal of Economics, Finance and Management Sciences. Vol. 4, No. 6, 2016, pp. 349-356. doi: 10.11648/j.ijefm.20160406.16

Received: September 26, 2016; Accepted: October 13, 2016; Published: November 5, 2016

\begin{abstract}
Since their creation, poles of competitiveness are becoming increasingly important in speeches and research literature. They have emerged as a relevant field of study and even a daily echo in business or the general press which report about changes in management practice within these clusters. Currently this structure, which is relatively nascent, focuses on the identification and dissemination of best practices among its actors. The aim of this paper is to outline a theoretical model of integration of inter- actors within the clusters. So, in order to develop this model, we explored a wide array of literature dealing with trust, clusters, and inter-organization relations. Finally, some issues related to the empirical examination of building trust are discussed. The contribution of this paper lies primarily in its study of the concept of trust in a multilateral context.
\end{abstract}

Keywords: Trust, Pole of Competitiveness, Cooperation, Cluster, Districts

\section{Introduction}

Manufacturing is a growth engine for the French economy as it is its main source of innovation ( $90 \%$ of R \& D) and competitiveness ( $80 \%$ of exports).

But this economy entered the last twenty years in a period of industrial change. Since 1978, the manufacturing industry has lost 1.5 million jobs. In addition, it faces strong price competition in labor intensive and technology-intensive activities, so the development of knowledge economy and the emergence of new competitors, the BRIC countries (Brazil, Russia, India, and China) whose weight changes itself market conditions, strengthens the innovation race.

The current objective of the French economy is to keep head above water until calm prevails in troubled waters. In economics, keeping one's head above water spells "competitiveness", and it requires not only to have an industrial base but also the ability to identify the necessary technological and industrial resources. Thus improving France's situation requires an ambitious investment in knowledge, which is based on a financial effort from the private and public actors in the fields of education and training, R \& D and innovation.
To meet this need and to create an environment conducive to innovation, a strategy of clusters has been adopted by both the Raffarin ${ }^{1}$ and the De villepin ${ }^{2}$ administration. This strategy not only brings together entrepreneurs, managers of research centers and higher education but also public officials, and aims to strengthen the link between these players and encourage them to work together to create value.

A study of these new types of organizations conducted by KPMG (2006) found that the biggest players are afraid of having to share years of investment on research and to improve performance with smaller ones. At the same time the smaller players fear the size effect which can result in an unbalanced cooperation, hence there is a strong sense of distrust among actors.

All of this demonstrates the critical role that trust plays as an essential element in trade and in the analysis of organizations as social systems. According to Delerue and Berard (2007), trust is regarded as a "lubricant" as the foundation for the functioning and efficiency of a social system. Simon (2007) as well as Pesqueux (2009) believes it is the factor needed to build "open" collaborative efforts that

1 Prime Minister of France from 6 May 2002 to 31 May 2005

2 Prime Minister of France from 31 May 2005 to 17 May 2007 
is to say not finalized. However the process of social integration is often difficult, particularly because of differences between the strategies, cultures, forms of organization, management styles and modes of communication. In contrast, studies suggest that the establishment of trust between partners can foster a mutually beneficial learning experience while allowing firms to protect their distinctive competencies (Ingham, 2008).

This article is organized as follows. In the first section, we present $\mathrm{PC}^{3}$, the second section deals with inter-actor cooperation in $\mathrm{PC}$ and the last emphasizes the notion of trust and proposes a model of construction of the latter.

\section{Poles of Competitiveness}

Globalization today embodies many opportunities and challenges for our society. France through its history, its cultural and social characteristics would have presented the conditions which foster local economic development dynamics.

\subsection{What is a Competitiveness Poles}

The word cluster, where a pole is a center of activity around which everything seems to "turn", with or without movement: attraction, growth pole, pole of development. Metaphorically, one pole attracts attention, companies, customers, migration, population. Regions are polarized by a city, a central location to which converges a field of attraction. Thus, PC's were designed as tools to promote the polarization around technological progress, innovation and quality. They are used to exploit the close relations to build these networks and form true "ecosystem for growth".

This device is a phenomenon still little studied because of its short existence. We can define it as a bunch of independent actors stabilized and consolidated (Piovesan, Pascal and Claveranne, 2007) and they form networks comprised of businesses and institutions specialized in a specific area (Messeghem \& Paradas, 2009). It represents a given territory, a conglomeration of companies, research centers and training organizations, engaged in a partnership approach (common development strategy), designed to create synergies around innovative projects conducted jointly by direction of a given market or markets (s (CIACT). Sixty clusters were created in July 2005 from a tender and a formal certification by the French government.

The poles are lightweight structures, usually under the 1901 law of associations, service companies, research centers and training.

\subsection{Mission and Objectives}

Their main task is to develop and structure three dimensions: innovation activities of enterprises, research and development, staff training.

The mix of actors, activities, products can generate new

3 Poles of competitiveness ideas, suitable for regional economic development.

From 2009, the PC has entered its second phase: version 2.0 of the poles. This approach provides a unique opportunity to reconnect with innovation, strengthen its industrial base, create new activities, and enhance its attractiveness. The balance of the poles is very positive and encouraging.

PCs are intended to strengthen French international economic competitiveness and growth and to promote employment by increasing the drive for innovation and improving France's attractiveness, through enhanced international visibility and an ecosystem that consists of a set of elements that contribute to innovation and generate growth.

For the problem of unemployment, according to the Association for the use of frameworks (APEC), the cluster effect is relatively weak in the short term. The only jobs created by the poles will be those induced by the organization of governance structures, those created by new partnerships and development projects.

Taking the example of foreign clusters, it took five to ten years after their launch for employment effects to be felt. Moreover, before talking about job creation, we must speak of maintenance, sustainability and consolidation of existing jobs.

\subsection{The Concept and Its Origins}

It stems from a reinterpretation of the theoretical work by Alfred Marshall (1890) analyzing mechanisms within a particular industry and some of his work on industrial districts. About a century later, Giacomo Becattini highlights this notion by stating that the industrial district is "a socioterritorial entity characterized by the presence of an active community of people and a population of firms in a geographical and historical given" (Becattini, 1992). According to this definition we see that Alfred Marshall is more relevant than ever and PC is finally nothing but an improved district (Raphael Suire, 2006).

In the early 90's, Michael Porter, Professor at Harvard Business School, popularized the concept of cluster and description of phenomena of business groupings. For him a cluster is, "a group of companies and institutions sharing same area of expertise, geographically close, interconnected and complementary "(Porter, 1999). Silicon Valley on the West Coast of the United States for the scientific community is a prime example of regional development (Suire, 2006).

But unlike industrial districts or clusters in North American, the poles have been approved by the State (Defélix, 2008), as U.S. clusters have no legal entity dedicated to their own governance. The massive government intervention in managing and supporting $\mathrm{R} \& \mathrm{D}$ centers is well-viewed even envied. It has no equivalent in other countries (Algoé, 2009) and in respect to districts, innovation, a priori, is not an end in itself, which is something entirely different in PCs.

This data leads us to conclude that PCs performance depends heavily on their hybrid nature between "industrial district" and "cluster". (Defélix, 2008) 


\subsection{The PC: A Complex Organization}

As the name indicates, a PC is composed of a plurality of actors: large groups, SMEs (on 4611 companies participating in clusters launched in 2005 by the French Government, 3905 (85\%) are SMEs), higher education institutions, and research organizations, both public and private.

Cluster policy was intended to network businesses of all sizes, research units and training centers, in the same territory and with a common theme, thus more often than not, poles have allowed actors who are not familiar with one another to work together. These actors are motivated by different objectives, have different perceptions of the environment, speak different languages and are largely strangers to each other. Also SMEs have some apprehension because they fear that they would not be able to protect their sensitive information in poles driven by large groups. Additionally SMEs, particularly those which are independent from groups, often lack the necessary skills to innovate through interaction. This explains the asymmetry that marks their relationship with large groups. This difficulty is due to a lack of practical networking and lack of professional intermediaries. Add to that the introduction of the concept of innovation-specific clusters in "the Anglo-Saxon sense (Bocquet \& Mothe 09). So these characteristics, history and nature of the relationship between actors, etc.., appear too varied so that the state imposes strict forms of governance (Denis Chabault, 2009).

\section{Inter-actors Relations at the Heart of PC}

The words designating such agreements are varied (alliances, partnerships, cooperation, collaboration, coopetition, etc.). We use in our research, these terms interchangeably to refer to "a collaboration agreement explicitly drawn for a specific time period, by which members of independent companies, interact to achieve the object" (Ingham, 1994). These relationships (or lack thereof) may determine the construction of the PC (Bossard, Bréchet, 2009) because in fact they show their ambition to bring together people from diverse backgrounds to make them work together on collaborative projects (Colle et al, 2009). Initiating these relationships appears both as a phase of building a network and as a phase of institutionalizing them. (Messeghem, Paradis, 2009). This policy plays on incentives rather than on coercion, and, it was deliberately and primarily intended to accelerate the birth of $\mathrm{R} \& \mathrm{D}$ projects (Fen Chong) since innovation--the concentration of companies and institutions of higher education and research-promotes the development of dense social networks (Saxenian, 2000), relationships between industry leaders and innovative startups promoting innovation in world-class clusters.

Several studies have confirmed that the size of collaborative management was a key for poles to succeed poles (Chabault 2009). This success is based on the ability to create interactions. It can be found in several PC
MINALOGIC including a world center located in the Grenoble-Isère (in south-eastern France) is specialized in micro-nanotechnologies. More than three out of four schools reported at least one cooperative relationship within the cluster MINALOGIC with another institution of the pole, a laboratory research or university. In total, each institution has developed, on average, six cooperative relations (INSEE), these figures indicate, as he says Porter (2000) that all cluster members are engaged in competitive relations and cooperation, $\mathrm{c}$ that is to say, because the territory coopetition carries externalities that are the interactions between local actors.

The cluster policy is based on the idea that it's not just actors but to juxtapose them to each other but to create an adequate environment to cooperate around development strategies driven by concrete projects.

The importance of inter-actors relations: what is their relevance in the innovation process?

Chinese strategist Sun Tzu mentioned in his famous book The Art of War, that the best strategy was the one who can win the war without fighting. Prescient vision of the military strategist who lived 500 years before Christ, is part of the unprecedented development of strategies for business cooperation. They are being presented as an exit door of different problems that affect business and particularly in terms of liquidity and innovation. Companies these days tend to look anywhere in the world for companies that are able to respond to unusual demands, instead of limiting progress to results obtained by domestic companies and laboratories.

Within the PC it is too early to assess the impact of this system on innovation and employment; most poles have shown thus far a promising dynamism. This dynamism is expressed particularly through the development of cooperation between actors (CMI-BCG, 2008), since their main objective was not only the participation of SMEs and large industrial and research institutions in the innovation process, but also for companies to run these collaborative projects by themselves because geographical proximity alone does not guarantee the development of beneficial relationships linked to innovation (Rallet and Torre, 2007). Other factors in the process of innovation including interactor interaction for instance, as in the case of Minalogic, is essentially the result of cooperation with other partners and it still is. The first obstacle that seems to hinder the development of innovation the most is the difficulty finding partners.

We can conclude that these new organizational forms appear to be most suited to today's economic environment. Some researchers even postulate that these new organizational forms can be used to reduce the gap between companies whose size and level of innovation are different.

We support the hypothesis that states that the process of innovation in clusters based on inter-organizational projects (Colle et al, 2009). These collaborative projects, which are fundamental for these poles, have created a new culture and led to a change in business behavior. 


\section{Trust}

Trust is a major element in life, without it no action is successful. It is important for the development of each individual, and society as a whole because without trust in oneself and the other, and in the future, no success is possible. It can also be a key asset for competition to the extent that it has a monetary value as the results of certain brands. It has therefore become a central social issue of concern to designers and managers of political, economic, social, and technological systems, structuring our civilization, determining the fate of humanity as not having trust is not only ineffective, but also and especially contrary universal ethics.

This is also why many researchers in recent decades have dedicated their time and effort to study trust and its origins and a day does not go by without the term trust being mentioned. Politicians, bankers, industrialists, shopkeepers, from top to bottom of the social ladder, Edgard Weber,2003 thinks that trust is as a process which places the individual in a position that does not take into account only the group and the, its environment to which he belongs, but of all mankind.

Research on the subject is abundant and the definitions are very diverse and varied. This concept is very abstract and multidimensional, it has been addressed by many scientific disciplines:

psychology (Rousseau, 1995), Sociology (Fukuyama, 1995), social psychology (Lewicki and Bunker, 1996) Economy (Dasgupta, 1988, Williamson 1993), Marketing (Castaldo, 2003), strategic management (Barney and Hansen, 1994), organizational behavior (Zaheer et al., 1998), so this notion, in particular, presents a ambiguous theoretical status. (M. Ingham and C. Mothe, 2003).

\subsection{Attempts to Define Trust}

In English, the notion of trust may seem simple to understand because the word is used in everyday language but in reality it encompasses many meanings; it is a polysemantic concept.

Recently researchers in management science arrived one the scene and research on trust has become one of the main areas of academic work in management and a recurring theme in research literature in the field.

Trust (or distrust symmetrically) has long been a topic of interest in literature, philosophy and social sciences. Fukuyama in his best seller "Trust: The Social Virtues and the Creation of Prosperity" (1995 (p.26) ) argues that "trust constitutes the expectations which are formed inside of a community governed by a consistent behavior, honest and cooperative, usually based on standards shared by the other members of this community." Many studies highlight the concept and present it as the main form of social control in inters organizational (Mélanie Antoine, 2006) or as a social phenomenon (Hauch, 1997) or a puzzle that connects the individual to society (Simmel, 1990). In their study, McEvily et al (2003: 92) suggested the following definition: "Trust is the willingness to accept vulnerability based on positive expectations about another's intentions or behaviors" as well Zucker (1986: p. 50) describes trust as "a logical set of expectations shared by all involved in an economic exchange."

Rousseau et al. (1998) and Sitkin and Roth (1993) define trust as a psychological state including the acceptance of vulnerability based on the expectation of positive behavior and intentions of the other party as it is the feeling experienced by one that the other will behave during interaction in a manner consistent with his interests (Cecile Gode-Sanchez 2003). We could give other definitions of trust, but most of the works in the psychological literature, sociological and managerial recently agree that trust is the acceptance of being vulnerable or the will to be vulnerable in relation to a partner (tick Ines, 2008).

\subsection{The Importance of Trust in the PC}

The emergence of new organizational forms (networks,...) and development strategies of alliances has led to new reflections on trust and its importance.

It seems more and more crucial for both academics and for practitioners or consultants. It is the glue that holds relationships together and weave the societal fabric that can offers security and a purpose to life. It enables people to live without having to control all the uncertainties and inexplicable situations (Andrew H. Van de Ven, 2004) and plays a central role in relations between and within organizations (Hauch, 1997), because a high level trust can increase employee satisfaction and improve customer satisfaction and organizational performance.

We found that several authors have shown that trust is an engine of firm as well as network governance and can fill gaps in a contract (Piovesan, Pascal \& Claveranne, 2007)

\subsection{The Dimensions of the Perception of Inter-organizational Trust}

The debate on the multiple dimensions of trust seems to reach no consensus, although some attempts at synthesis are beginning to emerge in literature concerning this question. We limit ourselves here to an analysis of trust in a collaborative environment and we note that perception is by definition subjective.

As highlighted in the literature, there are several terms to describe these dimensions, such as integrity, benevolence, good will, uncertainty, trust or credibility. (Margit Enke, 2006). According to (Mayer et al) measuring trust can be summarized in the ability, benevolence and integrity and in the same vein, (Bergadaà et al, 1999) propose that increased trust in any one agent is closely related to the increased trust in the skills of this agent or his good intentions in the exchange and related credibility or faith in his word.

Similarly, Pavlou (2002) identifies two dimensions of trust: credibility and benevolence. Both are described as perceived characteristics of the partner organization. And Ingham \& Mothe (2003) also opted for a three-dimensional conception of trust: 
- Credibility: associated with a company is the evaluation of its competence and technical know-how used to fulfill the expected values. Technical competence,

- Integrity or Loyalty: is the motivation of a company and honesty in meeting its promises regarding the terms of trade: ethical competence.

- Benevolence: is the favorable sentiment attributed to an actor to offer or to have a lasting and fair relationship and they argue that the relationships linking the three dimensions of trust are causal.

Based on these studies, we can conclude that the perception of inter-organizational trust in the PC is divided into three main components:

Perception of competence (technical abilities, skills and know-how) is a necessary antecedent and a basis for trust for business professionals. Signs of good will (the moral responsibility and positive intentions towards each other) are also necessary for the relying party to be able to accept a potentially vulnerable position.

Perception of benevolence that is the first level of trust suggests that an individual trusts another because he believes that he will meet his commitments without evidence of opportunism. (Simon, 2007).Thus business trust must be based on the awareness that decisions are consistent with a criteria and a well defined process. The firm must be confident that its partners plays the expected role of them in risk assessment and decision making. Companies need to be convinced that the rules are followed. Overall, a behavior characterized by integrity provides a foundation for that trust.

Perception of credibility (the belief in the ability of partners to carry out its work effectively and seriously). The second level suggests an individual trusts another because the latter has the requisite abilities and skills (Simon, 2007).

\subsection{Build a Model of Inter-actors Trust in the PC}

The thesis of the alternative modes of governance in the corporate networks between formal contract and informal trust has long prevailed, and we therefore assume that trust among different actors has a positive impact on the performance of pole.

Most research which has been conducted throughout the last thirty years involves the study of a rather indirect trust in relationships among people (tick Ines, 2008) and in reviewing the existing literature there seems to be no consensus on an operational construct of trust (Bergadaà et al 1999). Louis Quéré (2005), sociologist, provides an explanation for this lack of theoretical work, he points out that the difficulties linked to trying to survey and build the conceptual foundations of trust are the multiplicity and heterogeneity of the phenomena and situations covered by the term. However, the author attempts to show the diversity through two forms of trust particularly studied, namely interpersonal trust and institutional trust.

On this basis, the question of building trust takes into account the factors and ways that allow for regulation of exchanges between individuals, groups or organizations. This relationship, positive or negative, can be related institutions and organizations, i.e. different ways producing values.

Building trust is not negligible. This is something that must be treated relentlessly and tirelessly. It is regarded as a process, it does not just happen and it cannot simply be ordered. It results from a contract altered during the deepening or duration of the relationship; from a renewed contract.. It takes time to build. It is never a priori. In the case of PC, this is indeed pertaining to build networks based on a dilution of the "limited trust" with "moderate opportunism" because the nature of relationships between partners is changing with trust (Cecile Gode-Sanchez). As another main difficulty raised by the organizations is network maintenance, the sine qua non of their efficiency (D. Chabault, 2009).

\subsection{Proposal and Modeling}

Trust is subject to many theoretical frameworks that lead to a conceptualization of trust as a process built, but not acquired within that PC which should be seen as a determining factor in the decision an actor of whether or not to cooperate with another actor. This model comes from an eclectic theoretical approach and our observations and intuitions. We focus on the specific behavior of partners in a relationship, and focus on the history of this relationship, including the nature of past links. We suggest that actors use behavioral strategies to promote trust in the exchange, and we consider the context of the relationship an important determinant of how trust emerges.

Moreover, the research hypotheses revolve around three elements:

The variables related to the pole of competitiveness

In a broader analysis (Ahuja, 2000) noted that dense networks facilitate trust and cooperation as opposed to less dense networks that are not suitable for looking for new ideas. Along the same lines, (Gulati, Nohria \& Zaheer, 2000) argue that networks increase trust and reduce transaction costs in several ways and they give access to better information about each other to better information and can significantly reduce information asymmetries.

Indeed the benefits of belonging to a PCs are not known until after the cluster is performed (Retour. D, 09). Their proximity effect limits the risk of opportunism (Hauch \& Idrissi, 09) despite the extreme heterogeneity in terms of inter-organizational relations (R. Bocquet Moth, 09).

It seems, therefore, appropriate to mention that regulation establishes procedures for coordination and an adequate framework of cohesion (Segrestin, 2006) and increases trust.

We also recognize that such trust is hard to acquire and thus is depends on time and transparent rules in order for the players manage to build lasting relationships (Fen Chong). Also, it is based on formal systems such as procedures and standards (Hummel and Rosendaal, 2001) and particularly system of trust that is indicative of the trust.

The variables related to the actors of the pole

It is important to observe whether companies of different sizes with specific vocations, very different legal structures are able to establish trust.

In this context, several authors have found that trust could 
be determined by the one's reputation, skills, past experience, the relative power of concerned parties resulting from a relationship of dependency, as well as other issues specific to the nature of organizations, such as size and culture (C. Koenig, and G. van Wijk, 1992).

We first notice that actors' reputation playes a key role in the literature about trust; that reputation is known as a combination of key features of achieving trust (Ferris, Jagannathan, and Pritchard, 2003) and is a condition for establishing a relationship of trust (Pesqueux Y., 2009). From this principle (Moth, 1996) are two types of trust:

Pre-existing trust which is mainly due to reputation and trust created throughout the relationship that arises more from experience and good reputation of the partner company.

Then most studies have emphasized reputation which is associated to the actors' performance, because an entrepreneur is only trustworthy because of the "trustor's" confidence in his performance and integrity. Such confidence is likely to be formed continuously with repeated interaction or good references (Wehmeyer \& Riemer, 2007). Ex ante, trust is based on social conventions, but ex post, these conventions are reinforced or weakened by the actors' experience khlif Wafa (2002) and the history of relations is related to past actors who structure their relationship Bertacchini \& Dou (2001).

Finally some authors emphasize the cultural aspect, we often trust the person who shares our cultural values (Rousseau et al., 1998).

Based on these proposals, we can sketch the construction of a trust model:

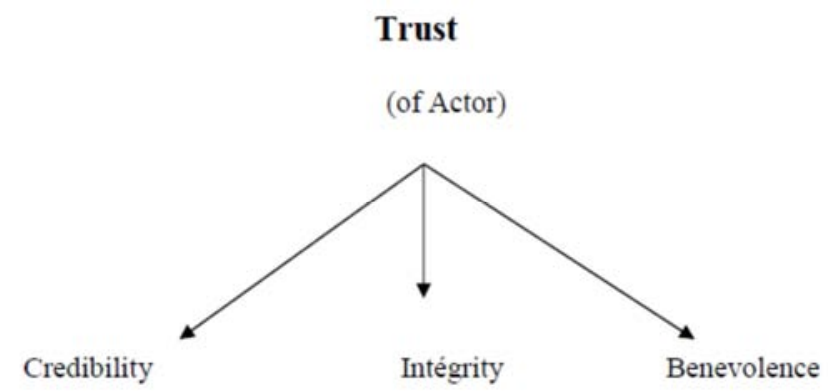

Figure 1. Model of inter organizational trust in competitiveness pole.

\section{Conclusion}

Although research is still quite limited for now, the PC appear as an emerging and promising field of research in the management sciences, which is why we deem it interesting to conduct a study on this subject. We found that work on trust are abundant in various fields and very important in business, for example, it is stated that "it takes 10 years to win the trust of a client, and 10 minutes to lose it! ".

For this reason, our research shows that the notion of trust has a real empirical existence in an area which was previously little studied and we show that the success of complex organization such as the PC is highly dependent on inter-actor relationships since their ability to cooperate is a strategic necessity for the world of today and tomorrow.

In addition to clarifying the concept and its role, our research highlights a model building the notion of trust summarizing some of the major factors that influence it.

We have argued that the relevance of this thesis is based on three points:

- Address the need to explore new avenues of research.

- Contribute to the advancement of knowledge on the concept of trust within the clusters

- Provide input which can contribute to improving trust.

Despite some limits, this work has generated a number of interesting results and interpretations.

To our knowledge, this work is the first to study trust in the context of the PC. The results of the study can take a response on its perception and the factors that influence it.

In general, our research is likely to make other contributions. It allows practitioner to consider concrete actions to implement to offset the lack of trust.

Given such limits, this study paves the way for further research.

- This research can be furthered by including PC as a sample and study the quality of trust, more specifically in a dynamic context.

- Research efforts should first be invested in the determination of quantitative indicators to measure the quality of each company.

- Identify all the elements that influence trust through interviews with managers of companies that are adhering to the $\mathrm{PC}$ in addition to the literature.

- Identify the link of these factors with trust in a given cluster.

\section{References}

[1] G. Ahuja, 'The duality of collaboration: inducements and opportunities in the formation of inter-firm linkages', Strategic Management Journal, Vol. 21, No. 3, 2000, pp. 317343.

[2] A. Rallet and And A. Torre (Eds.), Quelles proximités pour innover?, L'Harmattan, Paris, Collection 'Géographies en liberté », 2007, pp. 221.

[3] H. Andrew Van de Ven, The Appeal and Difficulties of Trust, Midwest Academy of Management Conference Luncheon Speech Minneapolis, MN, April 30, 2004.

[4] I. Antit, «Vers la constitution de la confiance optimale : réconcilier l'économique et le social», 19è congrès de l'AGRH, 2008, Dakar Sénégal.

[5] M. AOKI, Horizontal vs. Vertical Information Structure of the Firm, American Economic Review, 76 (5), 1986, pp. 971-983.

[6] P. Baillette and J. F. Lebraty, De la gestion des relations dans l'équipe virtuelle : la place de la confiance, AIM, 2002.

[7] G. Becattini, "The Marshallian industrial district as a socioeconomic notion", in Pyke, F. / Becattini, G. / Sengenberger, W. (1990) (eds.), Industrial districts and inter-firm cooperation in Italy, International Institute for Labour Studies, Geneva, 1992, pp. 37-51. 
[8] Y. Bertacchini and H. Dou, «The Territorial competitive intelligence: a network concept», Actes du Colloque VSST' 2001, Presses de l'Université Paul Sabatier p 101, Ecole Polytechnique de Catalogne, Barcelona October 2001.

[9] V. BOSSARD and J. P. BRÉCHET, «Projets et régulations dans les pôles de compétitivité», Conférence. AIMS 2009, Grenoble, 20 pages.

[10] S. Castaldo, 'Trust variety: conceptual nature, dimensions and typologies', The 19th IMP-Conference, Lugano, Switzerland, 2003.

[11] D. Chabault, «La gouvernance des pôles de compétitivité: entre émergence spontanée et figure imposé», XVIIIème Confernce of AIMS, Grenoble, june 2009.

[12] R. Colle, J. D. Culié, C. Defélix, F. Hatt and M. T. Rapiau, "Quelle GRH pour les pôles de compétitivité», Revue Française de Gestion, n¹90, 2009, pp. 143-161.

[13] P. Dasgupta, Trust as a Commodity. In Gambetta, D. (ed.) Trust: Making and Breaking Cooperative Relations. Department of Sociology, University of Oxford. 4, 1988, pp. 49-72.

[14] C. Defélix and al, «Prendre en compte le facteur humain au sein des pôles de compétitivité : la longue marche vers l'innovation sociale», Management et Avenir, $n^{\circ} 20$, november 2008.

[15] H. Delerue, C. Bérard, Dynamiques de la confiance dans les relations inter organisationnelles, Revue Française de Gestion, 175,2007, pp 125-138.

[16] C. Donada and G. Nogatchewsky, La confiance dans les relations interentreprises - Une revue des recherches quantitatives, Revue Française de Gestion, ${ }^{\circ}$ 175, 2007, pp. 111-124.

[17] E. Weber, Jusqu'où va la confiance? Revista CIDOB d'Afers Internacionals, $\mathrm{n}^{\circ}$ 61-62, 2003, pp. 215-219.

[18] S. Faerman, D. P. McCaffrey, and D. Van Slyke, Understanding interorganizational cooperation: Public-private collaboration in regulating financial market innovation. Organization Science 12 (3), 2001, pp. 372-388.

[19] S. Fen-Chong, Trois réponses régionales à un processus national, Réalités industrielles, may 2006.

[20] S. P. Ferris, M. Jagannathan and A.C. Pritchard, Too busy to mind the business? Monitoring by directors with multiple board appointments, Journal of Finance 63, 2003, pp. 1087-1111.

[21] F. Fukuyama, Trust: Social Virtues and the Creation of Prosperity. NY: Free press, 2009.

[22] G. Marandon, Au-delà de l'empathie, cultiver la confiance : clés pour la rencontre interculturelle, Revista CIDOB d'Afers Internacionals, ${ }^{\circ}$ 61-62, 2003, pp. 259-282.

[23] H. Hummels and H. E. Rosendaal, "Trust in scientific publishing” Journal of Business Ethics, Vol. 34, $\mathrm{N}^{\circ} 2,2001$, pp. $87-100$.

[24] M. Ingham, L'apprentissage organisationnel dans les coopérations, Revue Française de Gestion, Janvier-février 1994, pp. 105-119.

[25] M. Ingham, Pôles de compétitivité: réseaux de connaissances et d'innovation" 7ème symposium International de MDI
Business School, Algiers, June, 2008.

[26] J. Goo and K. Nam, «Contract as a Source of Trust Commitment in Successful IT Outsourcing Relationship: An Empirical Study» Proceedings of the 40th Hawaii International Conference on System Sciences, 2007.

[27] K. Wehmeyer and K. Riemer, Trust-building potential of coordination roles in virtual organizations, The Electronic Journal for Virtual Organizations and Networks, Volume 8, March 2007.

[28] W. Khlif, «Processus de construction de la confiance et configuration de contrôle de gestion», Revue Tunisienne des Sciences de Gestion- N7, 2007.

[29] C. Koenig and G. Van Wijk, " Alliances inter-entreprises : le rôle de la confiance" in Perspectives en. Management Stratégique, 2002.

[30] KPMG, Les pôles de compétitivité français : Prometteurs mais des défauts de jeunesse à corriger, december 2006, Paris.

[31] R. J. Lewicki and B.B. Bunker, Developing and maintaining trust in work relationships. In R. M. Kramer \& T. R. Tyler (Eds.), Trust in organizations: Frontiers of theory and research, 1996, pp. 114-139.

[32] -M. Max Evans and Anthony K. P. Wensley, Predicting the Influence of Network Structure on Trust in Knowledge Communities: Addressing the Interconnectedness of Four Network Principles and Trust Electronic Journal of Knowledge Management Volume 7 Issue 1 2009, pp. 41-54.

[33] A. Mbengue, Le fonctionnement dual des organisations, Revue française de gestion, juin juillet- août 1997, pp. 27-37.

[34] B. McEvily, V. Perrone and A. Zaheer, "Trust as an Organizing Principle”, Organization Science, 14(1), 2003, pp. 91-103.

[35] M. Antoine, Le succès des projets d'innovation interorganisationnels initiés dans le cadre d'une politique publique Réflexions et observations sur la nature de l'innovation et les modes de coopération, école de gestion de l'université de liège Belgique, 2007.

[36] K. Messeghem and A. Paradas, «L'émergence d'un pôle de compétitivité agroalimentaire: de l'encastrement à l'ambidextrie», Management et avenir, nº25, 2009, pp. 164183.

[37] M. Bergadaà, S. Graber and H. Mühlbacher (1999), «La confiance dans la relation tripartite vendeur-client-entreprise», XVème Congrès de l'Association Française de Marketing, Strasbourg - may 1999.

[38] P. A. Pavlou, "Consumer Acceptance of Electronic Commerce - Integrating Trust and Risk with the Technology Acceptance Model," International Journal of Electronic Commerce, Vol. 7, No. 2, 2002/03.

[39] Y. Pesqueux, «Un modèle organisationnel en «confiance coopération»"), Revue Management \& Avenir, n² 21, 2009, pp. 260-271.

[40] D. Piovesan, C. Pascal and J. P. Claveranne, "Les visages de la confiance, Restructurations et gouvernance des cliniques privées", 23èmes Journées des Economistes Français de la Santé, Lille, december, 2007.

[41] M. E. Porter, "Clusters and the New Economy." In Systems of Innovation: Growth, Competitiveness and Employment, 2000. 
[42] L. Quéré, «Les dispositifs de confiance dans l'espace public», Réseaux, 2005/4 no 132, pp. 185-217.

[43] R. Bocquet and C. Mothe, «Gouvernance et performance des pôles de PME», Revue Française de Gestion, vol. 35/190, 2009, pp.101-122.

[44] R. H. Coase, The Nature of the Firm, Economica, 1937.

[45] R. Suire, Cluster «créatif» et proximité relationnelle: Performance des territoires dans une économie de la connaissance, Canadian Journal of Regional Science, 2006.

[46] R. Gulati; N. Nohria and A. Zaheer, Strategic Management Journal, Vol. 21, No. 3, Special Issue: Strategic Networks, March 2000), pp. 203-215.

[47] D. M. Rousseau, M. Sitkin, R. Burt, and C. Camerer, Not so different after all: A cross-discipline view of trust. Academy of Management Review, 23 (3), 1998, pp. 393-404.

[48] D. M. Rousseau, Psychological contracts in organizations: Understanding written and unwritten agreements. Thousand Oaks, CA: Sage Publications, 1995.

[49] A. Saxenian, «Les limites de l'autarcie : Silicon Valley et Route 128». In Benko, Lipietz, eds, La richesse des régions : la nouvelle géographie socio-économique, PUF, Paris, 2000.

[50] B. Segrestin, Innovation et coopération interentreprises. Comment gérer les partenariats d'exploration? CNRS Editions, Collection CNRS économie, Paris, 2006, pp.175.

[51] G. Simmel, The Philosophy of Money Edited by David Frisby. Translated by Tom Bottomore and David Frisby. London and New York: Routledge, 2009.

[52] E. Simon, «La confiance dans tous ses états». Revue française de gestion, 175, 2007, pp. 83-94.
[53] S. B. Sitkin and N. L. Roth, "Explaning the limited effectiviness of legalistic remedies for trust/distrust", Organization Science, vol. 4, n 3, 1993, pp. 367-393.

[54] S. Tzu, l'art de la guerre, 2003.

[55] P. Trassaert, «Trialectique d'un réseau de firmes mis en place dans le but de coconcevoir un produit/système: Cas du systèmier automobile», Tutorat collectif des I.A.E., june 1997, Paris.

[56] V. Hauch, La communication inter-organisationnelle : une approche interactionniste des coopérations, $\mathrm{PhD}$ thesis, IAE Nice, 2007.

[57] M. Weber, Max, The Protestant Ethic and the Spirit of Capitalism, 1930, (trans T Parsons) Los Angeles: Roxbury 1996.

[58] O. E. Williamson, Economic Organization: Forms, Markest and Policy Control, New York, New York University Press, 1986, pp. 310.

[59] O. E. Williamson, "Calculated Trust, A Reply", Journal of Law \& Economics, University of Chicago Press, vol. 36 (1), pages 501-02, April 1993.

[60] A. Zaheer, B. McEvily and V. Perrone, Does trust matter? Exploring the effects of interorganizational and interpersonal trust on performance. Organization Science, 9 (2), 1998, pp. 141-159.

[61] L. G. Zucker, Production of Trust: Institutional Sources of Economic Structure, Research in Organizational Behavior, 8, 1986, pp. 53-111. 